\title{
An analysis of statistics on the capacity of tourism attractions between Mediterranean countries
}

\author{
G. Skonieczny \& B. Torrisi \\ Department of Economics and Territory, Branch of Economic Statistics, \\ University of Catania, Italy
}

\begin{abstract}
The theory on the economic development attributed to the tourism sector plays a central role in the growth process of some zones of the world. Therefore, to determine the competition level and economic attraction of a territory, it is necessary to measure the most important sectors. Today, the Mediterranean area represents one of the prime areas of attraction and destination of international tourism. It has registered satisfactory performance with tourist arrivals. Within a similar trend, various countries have for many years programmed and mapped out the progress of the tourism sector with economic strategies of medium to long term periods.

In reality, the research of a synthetic index and of the source of information regarding the characteristics of the tourism sector becomes an interesting instrument for developmental policies.

However, when looking from a theoretical level to effectuate confirmation of the quantity of tourism, the difficulties presented are: availability of the basic data, verification of the minimum requisites of homogeneity and area comparability between different areas, specification of the correct modality of statistical handling, the building of indicators and so on.

To study the sector's behaviour in the Mediterranean area, it is necessary to obtain the characteristics of supply and demand that are not always common. These different characteristics influence the tourism sector's success and development and produce different effects in the results of tourism balance.

On grounds of these considerations, this present research analyses the structural and infrastructural characteristics of the tourism sector of Mediterranean countries in order to formulate a picture of the competitive capacity of the analysed territory. Such an objective has been attained through the use of methodological statistics outlaying the construction of indicators and the study of homogeneous and non-homogeneous territory at the base of analysed variables.
\end{abstract}

Keywords: classification, territorial comparisons, tourism attraction index. 


\section{Introduction}

In the overall framework of competitiveness within Mediterranean countries, the surprising performance in the last 20 years from some of these countries must be recorded, i.e.: Spain $+200 \%$, Turkey $+800 \%$, Egypt $+300 \%$, Morocco $+93 \%$, Tunisia $+137 \%$, Greece $+91 \%$ and Malta $+256 \%$.

These results must be considered in the main tangible and intangible factors when determining tourism in a given location.

Among the tangible factors it is important to consider the following: the diffusion of accommodation that is more integrated with local realities; the competitive mix of quality/price factors; ecologic/environmental aspects; the historical, artistic and cultural heritage; the tendency to spread holidays more equally throughout the year; the ability to offer an "integrated product" plus the cost, velocity, security, frequency, comfort, affordability and global quality of transport.

Whilst among the intangible factors, consider the possibility of crossreferencing the available information relating to the motivation of the traveller with the typology of the tourist resort of within which the hotels are found. The prevalence of these needs is a determining factor in the choice of destination location.

The attraction capacity of territorial tourism, the non-transferability of some natural assets, its artistry and history create strong elements of differentiation between the various destinations, determining the territory's positioning in the tourist sector. Therefore, ease of access becomes an added value to the competitiveness of one area over another. Integration between infrastructure and services increases the degree of a destination's appeal.

The literature mentions three different approaches in the analysis of the factors qualifying the territory's tourist appeal: 1) a formal approach, which classifies the attractions in relation to the natural, technological, social, cultural and monumental environment; 2) a spacial approach that classifies the attractions according to their "geographic scope"; 3) a cognitive approach, which interprets the attractions in relation to the tourists' experiences.

From the marketing perspective, the more coherent prospect in the analysis of the attraction's capacity appears to be cognitive, while the other approaches seem more of a structural nature and less of a marketing philosophy [1-3].

In relation to these definitions and targets proposed, it becomes impossible for us to provide a mapping of the competitiveness and attractiveness of a country based on the aforementioned parameters. Therefore, due to missing data and statistical information relating to the intangible aspects, we must rely on the officially available data related to the tangible variables. Therefore, because of missing data and statistical information regarding the intangible aspects, it is necessary to base our analysis on the officially available data related to the variable tangibles. 


\section{The sources, the data, and the indicators}

The starting point of this analysis is the collection of data and the selection of the indicators used. The latter include [2]:

- Specialization index

$$
{ }^{t} I_{i}{ }^{s p e c}=\left(x_{i j t} / \sum_{j} x_{i j t}\right) /\left(\sum_{i} x_{i j t} / \sum_{i} \sum_{j} x_{i j t}\right)
$$

where $\mathrm{X}_{i j t}$ represents the number of structures $j$-th considered, in the $i$-th country, at the time $t=1995-2006, \forall i=1 \ldots 12$ Mediterranean countries, $j=1 \ldots n$ different types of accommodation.

- Diversification receptive index

$$
{ }^{t} I_{i}{ }^{\text {div.ric }}=\sum_{j} A_{i j t} / P o p_{-} \operatorname{Re} s_{i t}
$$

where $\mathrm{A}_{i j t}$ represents total tourist arrivals in the $i$-th country, in the $j$-th structure, at the time $t=1995-2006, \forall i=1 \ldots 12$ Mediterranean countries, compared to the resident population (Pop.Res.) in the Country $i$-th at time $t$.

- $\quad$ Notoriety index

$$
{ }^{t} I_{i}^{n o t}=\sum_{j} P_{i j t} / \sum_{i} \sum_{j} P_{i j t}
$$

where $P_{i j t}$ represents the total tourist presence in the $i$-th country, in the $j$-th structure, at the time $t=1995-2006, \forall i=1 \ldots 12$ Mediterranean countries.

- $\quad$ Social load index

$$
{ }^{t} I_{i}^{s o c}=\sum_{j} P_{i j t} / P o P_{-} \operatorname{Re} s_{i t}
$$

where $P_{i j t}$ represents total tourist presents in the $i$-th country, in the $j$-th different types of accommodation, at the time $t=1995-2006, \forall i=1 \ldots 12$ Mediterranean countries, compared to the resident population (Pop.Res.) in the Country $i$-th at time $t$.

- $\quad$ Load the catering index

$$
{ }^{t} I_{i}^{\text {cat.rist. }}=A_{i t} / \sum_{j} x_{i j t}
$$

where $\mathrm{A}_{i j t}$ represents total tourist arrivals in the $i$-th country, in the $j$-th structure, at the time $t=1995-2006, \forall i=1 \ldots 12$ Mediterranean countries, compared to the total number of restaurant and entertainment structures $\left(\mathrm{X}_{i j t}.\right)$ in the $i$-th country $\forall j=1 \ldots 5$ different typologies of hospitality (ice-cream shops, bars and pubs café, disco pub, restaurants, cinema). This index is the potential customers of the services of the productive sector that guide and express the ability to serve the tastes and needs of a variety of customers.

- $\quad$ Promotion tourist index

$$
{ }^{t} I_{i}{ }^{p r o m}=\sum_{j} x_{i j t} / P_{P} p_{-} \operatorname{Re} s_{i t}
$$


where $\mathrm{X}_{i j t}$ is the size of tourist agencies and tour operators present in the country $i$-th at the time $t=1995-2006, \forall i=1 \ldots 12$ Mediterranean countries, $\forall j=1,2$ (tourist agencies and tour operators), compared to the resident population (Pop.Res.) in the Country $i$-th at time $t$.

- Receptive employment index

$$
{ }^{t} I_{i}^{o c c .}=\sum_{j} P_{i j t} / \sum_{j} x_{i j t}
$$

where $P_{i j t}$ represents total tourist presence in the $i$-th country, in the $j$-th different types of accommodation, at the time $t=1995-2006, \forall i=1 \ldots 12$ Mediterranean countries, $\forall j=1 \ldots 7$ different types of accommodation (hotels, villages, campsites, B\&B, apartments, hostels, farm holidays), compared to the total overall of the accommodation facilities of the country $i$-th.

- Park use index

$$
{ }^{t} I_{i}^{u t i l . p a r c h .}=\sum_{j} P_{i j t} / \sum_{j} x_{i h j t}
$$

where $P_{i j t}$ represents total tourist presence in the $i$-th country, in the $j$-th different types of accommodation, at the time $t=1995-2006, \forall i=1 \ldots 12$ Mediterranean countries, $\forall j=1 \ldots 7$ different types of accommodation, compared to the total overall of parks and reserves (natural reserves, national parks, natural areas and marine reserves, regional parks and reserves, parks) $\forall h=1 \ldots 5$ of the $i$-th country.

- Cultural use index

$$
{ }^{t} I_{i}{ }^{u t i l . c u l t .}=\sum_{j} P_{i j t} / \sum_{j} x_{i h j t}
$$

where $P_{i j t}$ represents total tourist presence in the $i$-th country, in the $j$-th different types of accommodation, at the time $t=1995-2006, \forall i=1 \ldots 12$ Mediterranean countries, $\forall j=1 \ldots 7$ different types of accommodation, compared to the total overall cultural facilities (conferences, dwellings, museums and institutes) $\forall$ $h=1 \ldots 3$, in the $i$-th country.

These indices (composed index) were constructed from a number of simple indications linked to the tourism sector (see Table 1).

Each composed index is structured in relation to a series of components, see Table 2 .

For the composed index, estimated for each country, a weighted average has been calculated in relation to the weight associated with each composed index for the territory (for order of importance - subjective weighing).

\section{The methodology employed}

In order to sample the territorial division of the Mediterranean in relation to each of the aspects that countersign according to the hypotheses made, the different types of behaviour of the phenomenon and groups of variables have been used individually according to what has been indicated beforehand. Though the factorial weights obtained from the 34 variables (simple index) have obtained 
Table 1: $\quad$ List of simple index.

tourism attraction's capacity of:

- nature reserves (state and regional) - tourist ports - National Parks - catering firms dwellings - commercial centres - campsites - bars and cafés - natural areas and marine reserves - other state or regional areas -hotels - vacation houses and mountain refuges - tourist villages - cableway transport - pubs and disco-pubs - parks, museums and institutes - companies - ice firm - mountain communities - cinema - convention centres - bed \& breakfast - company spas - farm holidays - travel agencies and tour operators - local spas - tourist calls- hostesses

- the positioning of the hotel offer index - endowment hotel index - diversification receptive index

- notoriety index - social load index

Table 2: $\quad$ List of simple index for interest areas.

\begin{tabular}{|c|c|c|c|}
\hline $\begin{array}{l}\text { Cod. } \\
\text { Var. }\end{array}$ & Interest's area & Components indicators & \multirow[t]{3}{*}{ Index } \\
\hline 8 & Cultural allocation & $\begin{array}{l}\text { Historical - dwellings - congressional } \\
\text { museums }\end{array}$ & \\
\hline 4 & Port infrastructure & Touristic landings - tour boats & \\
\hline 1 & $\begin{array}{l}\text { Infrastructure - } \\
\text { receptive }\end{array}$ & $\begin{array}{l}\text { Farm holidays - diversification receptive } \\
\text { index - hostels - holiday houses - B\&Bs - } \\
\text { camping - villages- hotel mountain huts }\end{array}$ & \\
\hline 5 & $\begin{array}{l}\text { Infrastructure - } \\
\text { receptive spa }\end{array}$ & Company spas & \\
\hline 6 & $\begin{array}{l}\text { Mountain } \\
\text { infrastructure }\end{array}$ & Cableway transport & \\
\hline 7 & Natural infrastructure & $\begin{array}{l}\text { Mountain communities - resort spas - nature } \\
\text { reserves - National Parks- marine reserves - } \\
\text { regional parks - amusement parks }\end{array}$ & ${ }^{t} \mathbf{I}_{i}^{\text {spec }}$ \\
\hline 3 & $\begin{array}{l}\text { Services - restaurants } \\
\text { and entertainment }\end{array}$ & $\begin{array}{l}\text { Ice-cream shops - bars and cafés - pubs and } \\
\text { disco-pubs - restaurants - cinemas - load } \\
\text { index of restaurant and entertainment }\end{array}$ & ${ }^{1} \mathbf{I}_{i}{ }^{\text {car.rist. }}$ \\
\hline 2 & External visibility & $\begin{array}{l}\text { The promotional ability tourism index - rate } \\
\text { of employment annual average- notoriety } \\
\text { index - Social load index - average utilization } \\
\text { rate tourist parks and reserves - potential rate } \\
\text { of use cultural facilities }\end{array}$ & $\begin{array}{l}{ }^{t} \mathbf{T}_{i} \\
{ }^{t} \mathbf{I}_{i} \text { iot. } \\
{ }^{\text {occ. }} \mathbf{I}_{i}^{\text {soc }} \\
{ }^{{ }^{t}} \mathbf{T}_{i}^{\text {util.parchi }} \\
{ }^{t} \mathbf{T}_{i}^{\text {util.cult. }}\end{array}$ \\
\hline
\end{tabular}

eight macro composed indexes [2], the object is successive elaboration with the Cluvar technique (cluster variables). (This technique is aimed at the identification of homogeneous groups and the relations between the units (routes) (relations between the individual units and the clusters identifying among the variables those that have contributed the most to the ties between the couples of units.) In particular, a data table is given where xij represents the 
determination of the $\mathrm{Xj}$ variable per $\mathrm{j}=1 \ldots \ldots \mathrm{m}$ on the Ui unities per $\mathrm{i}=1, \ldots . \mathrm{n}$. Let $\mathrm{Sn}, \mathrm{m}$ be the correspondent table of standardized values and $\mathrm{dj}$ the most opportune distance. The matrices $m$ of distance are determined. The technique of grouping "Cluvar" has been used for this aim (further details are given in Skonieczny [4])

In particular, the Cluvar technique was adopted with the intent not only to extrapolate the homogeneity and non-homogeneity among territorial units, but also to underline the aspect of variables that interact in the system and the whole of the relations among unities groups.

Differently from classical techniques, Cluvar gives the possibility of determining aggregations among statistic techniques, underlining both the variables that significantly influence cluster determination and the weight that those have on the aggregation definition.

The use of groups of variables has allowed a thematic analysis of the phenomenon and its articulations on the territory; it does not allow, however, a vision of the groups as a consideration of the single aspects and of the events caused by the integration between them [4-5]. Often the accumulations of joint causes generate demonstrations and different behaviour to the usual interpretive models [4-5].

In general, the goal of the analysis is to detect meaningful underlying dimensions that allow the researcher to explain observed similarities or dissimilarities (distances) between the investigated objects. In factor analysis, the similarities between objects (e.g., variables) are expressed in the correlation matrix.

\section{The results}

The following results have been obtained on the basis of the adopted methodology and in relation to the underlined aspects: there is improvement between 1995 and 2006 in the visibility, in the infrastructure receptive degree, in some countries more than others, which led to an increased competitiveness between countries and consequently greater uniformity of tourist offers in the Mediterranean area, see Table 3.

These results show overall homogeneity of tourism attraction capacity between the Mediterranean countries analysed, characterizing unambiguity and standardisation of tourist offers, for France and Turkey in particular.

In addition, Cluvar has indicated how, within aggregations of similarity with less internal variability, only clusters are formed, compared to the greater variability indicated among other aggregations present in the same cluster, see Table 4.

From the analysis there are changes in similarity between the territorial units that occurred between 1995 and 2006. For example, the aggregation of similarity of Spain compared to countries like Portugal and ex Yugoslavia was differentiated in 2006. This is also what happened for Italy, Israel, Egypt and France. 
Table 3: $\quad$ Results of the composed index by country.

\begin{tabular}{|c|c|c|c|c|c|c|c|c|}
\hline & 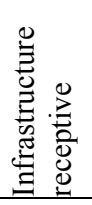 & 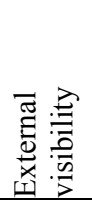 & 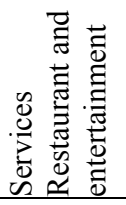 & 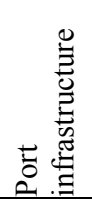 & 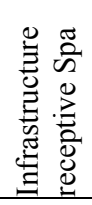 & 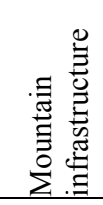 & 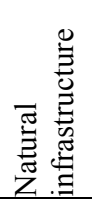 & 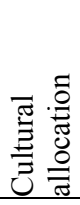 \\
\hline \multicolumn{9}{|c|}{1995} \\
\hline France & 0,97 & 5,50 & 1,003 & 1,001 & 0,989 & 2,2869 & 1,018 & 1,000 \\
\hline Greece & 1,54 & 1,00 & 1,018 & 1,025 & 1,198 & 0,4143 & 0,837 & 1,085 \\
\hline Egypt & 1,09 & 1,36 & 1,009 & 1,018 & 0,791 & 0,1439 & 0,533 & 2,759 \\
\hline Portugal & 0,88 & 0,88 & 1,020 & 0,973 & 1,010 & 1,3830 & 1,036 & 1,011 \\
\hline Israel & 1,28 & 0,09 & 0,915 & 0,938 & 1,005 & 0,2446 & 1,099 & 1,007 \\
\hline Turkey & 0,63 & 1,52 & 1,000 & 0,984 & 0,968 & 0,1376 & 1,052 & 0,989 \\
\hline ex Yugoslavia & 1,01 & 0,08 & 1,044 & 0,983 & 0,980 & 1,6405 & 0,900 & 0,817 \\
\hline Spain & 1,00 & 1,06 & 1,060 & 1,039 & 1,041 & 0,5840 & 0,935 & 0,880 \\
\hline Malta & 0,75 & 0,52 & 0,959 & 1,023 & 0,541 & 0,0881 & 0,876 & 1,068 \\
\hline Morocco & 1,71 & 0,82 & 0,809 & 0,920 & 0,686 & 0,0479 & 0,936 & 1,026 \\
\hline Italy & 0,93 & 1,23 & 1,099 & 1,017 & 1,114 & 1,5356 & 0,975 & 1,019 \\
\hline Tunisia & 0,79 & 0,85 & 0,875 & 0,931 & 0,569 & 0,1049 & 0,410 & 0,978 \\
\hline \multicolumn{9}{|c|}{2006} \\
\hline France & 0,97 & 4,78 & 0,999 & 0,994 & 0,929 & 2,2510 & 1,118 & 0,995 \\
\hline Greece & 1,34 & 0,51 & 1,021 & 1,029 & 1,145 & 0,4442 & 0,896 & 1,043 \\
\hline Egypt & 0,95 & 1,79 & 1,008 & 1,018 & 0,938 & 0,1380 & 0,430 & 2,624 \\
\hline Portugal & 0,97 & 0,46 & 1,025 & 0,973 & 0,913 & 0,8653 & 1,086 & 1,048 \\
\hline Israel & 1,38 & 0,01 & 0,920 & 0,941 & 1,081 & 0,0804 & 1,119 & 1,004 \\
\hline Turkey & 0,63 & 8,98 & 0,958 & 0,988 & 0,734 & 0,1161 & 0,897 & 0,984 \\
\hline ex Yugoslavia & 1,06 & 0,61 & 1,043 & 0,985 & 1,163 & 2,1238 & 0,728 & 0,839 \\
\hline Spain & 1,03 & 1,07 & 1,053 & 1,040 & 1,166 & 0,8353 & 0,941 & 0,875 \\
\hline Malta & 0,68 & 0,28 & 0,982 & 1,020 & 0,582 & 0,0332 & 0,828 & 1,082 \\
\hline Morocco & 1,42 & 0,52 & 0,810 & 0,925 & 0,585 & 0,0335 & 0,753 & 1,022 \\
\hline Italy & 0,93 & 1,35 & 1,089 & 1,016 & 1,085 & 1,4796 & 0,964 & 1,026 \\
\hline Tunisia & 0,73 & 0,47 & 0,863 & 0,930 & 0,644 & 0,0380 & 0,467 & 0,876 \\
\hline \multicolumn{9}{|c|}{ weight } \\
\hline & 0,18 & 0,23 & 0,1 & 0,05 & 0,13 & 0,01 & 0,15 & 0,15 \\
\hline
\end{tabular}

For all homogeneity between Mediterranean countries, it should be emphasised that the average weighted overall index of tourism attraction capacity showed changes in the graded list of attractiveness between 1995 and 2006. In fact, it is possible to draw a graded list of Mediterranean countries with greater and lesser ability to attract tourism (see Table 5). Among the best are France, Turkey and Egypt, with a worsening registered by Morocco. 
Table 4: $\quad$ Results of Cluvar clustering.

\begin{tabular}{|c|c|c|c|c|c|c|c|}
\hline \multicolumn{4}{|c|}{ Cluvar 1995} & \multicolumn{4}{|c|}{ Cluvar 2006} \\
\hline & \multicolumn{2}{|l|}{ Cluster n. 1 (C1) } & \multirow{2}{*}{$\begin{array}{c}\text { Cod. Var. } \\
1-2-3-4-5-6- \\
7-8\end{array}$} & & \multicolumn{2}{|c|}{ Cluster n. 1 (C1) } & \multirow{2}{*}{$\begin{array}{l}\text { Cod. Var. } \\
1-3-4-5-7-8\end{array}$} \\
\hline Portugal & Spain & 0,17 & & France & Portugal & 0,26 & \\
\hline Spain & Ex Yugoslavia & 0,35 & $1-3-4-5-7-8$ & Portugal & $\begin{array}{l}\text { France -> } \\
\mathrm{Cl}(1)\end{array}$ & 0,26 & $1-3-4-5$ \\
\hline $\begin{array}{l}\text { Ex } \\
\text { Yugoslavia }\end{array}$ & $\begin{array}{l}\text { Portugal -> } \\
\mathrm{Cl}(1)\end{array}$ & 0,17 & \multicolumn{2}{|l|}{$1-2-3-4-5-6-7-8$} & \multicolumn{3}{|c|}{ Altra relazione: } \\
\hline \multicolumn{4}{|c|}{ Altra relazione: } & Greece & Israel & 0,35 & $\begin{array}{c}1-2-3-4-5-6- \\
7-8\end{array}$ \\
\hline Greece & Malta & 0,26 & $3-4-7-8$ & Israel & Morocco & 0,52 & $\begin{array}{c}1-2-3-4-5-6- \\
7-8\end{array}$ \\
\hline Malta & Tunisia & 0,52 & $\begin{array}{c}1-2-3-4-5-6- \\
7-8 \\
\end{array}$ & Morocco & Tunisia & 0,43 & $2-3-4-5-6-8$ \\
\hline Tunisia & Morocco & 0,26 & $2-3-4-5-6-8$ & Tunisia & Malta & 0,26 & $1-2-3-4-5-6-8$ \\
\hline Morocco & Israel & 0,17 & $\begin{array}{c}1-2-3-4-5-6- \\
7-8\end{array}$ & Malta & Turkey & 0,17 & $1-3-4-5-6-7-8$ \\
\hline Israel & $\begin{array}{l}\text { Portugal > } \\
\mathrm{Cl}(1)\end{array}$ & 0,26 & $4-5-7-8$ & Turkey & $\begin{array}{l}\text { France } \sim> \\
\mathrm{Cl}(1)\end{array}$ & 0,26 & $\begin{array}{c}1-2-3-4-5-6- \\
7-8\end{array}$ \\
\hline \multicolumn{4}{|c|}{ Altra relazione: } & \multicolumn{4}{|c|}{ Altra relazione: } \\
\hline France & Turkey & 0,35 & $3-4-5-8$ & Egypt & Spain & 0,17 & $\begin{array}{c}1-2-3-4-5-6- \\
7-8 \\
\end{array}$ \\
\hline Turkey & $\begin{array}{l}\text { Portugal > } \\
\mathrm{Cl}(1)\end{array}$ & 0,17 & $3-4-7-8$ & Spain & Ex Yugoslavia & 0,26 & $1-3-4-5-7-8$ \\
\hline \multicolumn{4}{|c|}{ Altra relazione: } & $\begin{array}{l}\text { Ex } \\
\text { Yugoslavia }\end{array}$ & $\begin{array}{l}\text { Greece } \sim> \\
\mathrm{Cl}(1)\end{array}$ & 0,35 & $1-2-3-4-5-7-8$ \\
\hline Italy & France $\sim>\mathrm{Cl}(1)$ & 0,43 & $1-3-4-5-7-8$ & & Alt & relazic & \\
\hline \multicolumn{4}{|c|}{ Altra relazione: } & Italy & $\begin{array}{l}\text { Spain }> \\
\text { Cl(1) }\end{array}$ & 0,26 & $\begin{array}{c}1-2-3-4-5-6- \\
7-8\end{array}$ \\
\hline Egypt & $\begin{array}{l}\text { Turkey } \sim> \\
\mathrm{Cl}(1)\end{array}$ & 0,26 & $2-3-4-5-6$ & & & & \\
\hline
\end{tabular}

Table 5: Results of average weighted overall index of tourism attraction capacity by country.

\begin{tabular}{|ll|ll|}
\hline \multicolumn{1}{|c|}{1995} & & \multicolumn{2}{|c|}{2006} \\
\hline France & 2,05 & Turkey & 2,70 \\
Egypt & 1,26 & France & 1,88 \\
Greece & 1,11 & Egypt & 1,32 \\
Italy & 1,07 & Italy & 1,09 \\
Turkey & 1,05 & Spain & 1,02 \\
Morocco & 1,01 & Greece & 0,96 \\
Spain & 1,00 & ex Yugoslavia & 0,89 \\
Portugal & 0,96 & Portugal & 0,88 \\
Israel & 0,84 & Israel & 0,85 \\
Malta & 0,76 & Morocco & 0,84 \\
ex Yugoslavia & 0,76 & Malta & 0,70 \\
Tunisia & 0,75 & Tunisia & 0,66 \\
\hline
\end{tabular}




\section{Conclusions}

In conclusion we can say that estimating the attraction's capacity of locality, using tangible factors, does not always present significant results. The default of the intangible database to integrate with statistical information previously used is a reductive factor for significant results and analysis.

Moreover, the attempt to use empirical analysis to establish the link between theory and practice lead to incompatibilities and inconsistencies often being generated. The means to empirically define the tangible and intangible aspects of tourism are reflected in the data and in the official statistics.

There is, therefore, reductive theoretical recruitment, when the official statistical sources remain standardized to traditional observations, leaving space for significant statistical processing.

Despite this, in this work we have delivered a first attempt at empirical analysis, which leaves room for further reflection and attempts at empirical analysis.

\section{References}

[1] Casarin Francesco Il marketing dei prodotti turistici. Specificità e varietà ed. Giappichelli 2007;

[2] Busetta P., Torrisi B. "Aspetti statistici del turismo in Sicilia” in Lo sviluppo del turismo in Sicilia. Potenzialità, problemi, prospettive di intervento a cura di Rosario La Rosa ed. Franco Angeli 2006;

[3] LaLicata P. Torrisi B., Stratejileri B.A. "Information search strategies: differences between internet and non internet users", in First Tourism Congress of Mediterranean Countries April - Turkey 2002;

[4] Skonieczny G. Cluvar plus: un metodo di classificazione con la selezione delle variabili, in Giornate di analisi dei dati multidimensinale 1995;

[5] Skonieczny G., Torrisi B. Cluvar: a grouping technique of statistic units and of variables selection, in proceeding $42^{\circ}$ Congress of the European Regional Science Association (ERSA), University of Dortmund, Germany, 2002. 